\title{
Pelatihan Pembuatan Sabun dan Lilin Dari Limbah Minyak Jelantah
}

\author{
Khairunnisa*, Salsabila Zara Mahasin \\ Universitas Negeri Malang, Jl. Semarang No. 5 Malang, Jawa Timur, Indonesia \\ *Penulis korespondensi, Surel: khairunnisa.1808116@students.um.ac.id
}

Paper received: 2-11-2021; revised: 17-11-2021; accepted: 23-11-2021

\begin{abstract}
Abstrak
Limbah rumah tangga merupakan limbah yang dihasilkan dalam rumah tangga dari proses keberlangsungan kehidupan sehari-hari. Mengingat banyaknya rutinitas rumah tangga yang berdampak pada munculnya limbah, membuat lingkungan sekitar juga turut memperoleh dampak negatif yang ditimbulkan dari limbah tersebut. Dampak tersebut dapat berupa pencemaran lingkungan, penurunan tingkat kebersihan air dan secara tidak langsung dapat berdampak pada tingkat kesehatan masyarakat sekitar. Mengingat pentingnya menjaga kondisi lingkungan, komunitas PKK (Pemberdayaan Kesejahteraan Keluarga) beserta mahasiswa MBKM Universitas Negeri Malang menyelenggarakan pelatihan pembuatan sabun dan lilin dengan memanfaatkan limbah rumah tangga yaitu berupa minyak jelantah. Pelatihan ini dihadiri oleh anggota komunitas PKK (Pemberdayaan Kesejahteraan Keluarga) serta perwakilan dari 17 dusun yang ada di desa Donomulyo. Kegiatan ini diharapkan dapat diterapkan oleh seluruh rumah tangga yang ada di desa Donomulyo sebagai upaya untuk mengurangi tingkat produksi limbah rumah tangga, pemanfaatan limbah menjadi benda pakai dalam kebutuhan sehari-hari serta dapat menjadi keahlian dengan daya jual yang dapat dipergunakan oleh masyarakat.
\end{abstract}

Kata kunci: pelatihan; minyak jelantah; sabun; lilin

\section{Pendahuluan}

Limbah merupakan sebuah hal yang patut ditangani dengan amat serius, salah satu penyumbang limbah dalam jumlah yang amat besar adalah rumah tangga. Limbah rumah tangga merupakan hasil pembuangan segala hal yang sudah habis guna di dalam rumah tangga, seperti sampah dapur, sampah sehari-hari dan lain sebagainya. Limbah rumah tangga yang dihasilkan oleh rumah tangga memiliki jumlah yang amat besar, pasalnya limbah rumah tangga dihasilkan dalam jangka waktu harian dan terus-menerus bertambah. Indonesia, negara dengan jumlah penduduk sebanyak lebih dari 270 juta dengan jumlah rumah yang berdiri sebanyak lebih dari 45 juta. Akumulasi jumlah limbah rumah tangga di Indonesia menjadikan limbah rumah tangga sebagai penyumbang terbesar sampah di Indonesia yaitu sebesar 37,3\% dari 67,8 juta ton sampah di Indonesia ada tahun 2020 (KLHK, 2020).

Persentase jumlah limbah rumah tangga yang dihasilkan sudah memasuki level yang amat serius bagi kesejahteraan lingkungan, hal ini dikarenakan imbas dari produksi limbah yang memiliki resiko negatif seperti pencemaran lingkungan baik di darat maupun laut, dan perubahan iklim yang berbahaya bagi kesejahteraan dunia secara umum. Salah satu limbah yang banyak dihasilkan oleh rumah tangga adalah limbah minyak, atau yang dikenal dengan minyak jelantah. Minyak jelantah merupakan minyak yang telah digunakan untuk berbagai keperluan seperti memasak, sehingga tidak dapat lagi digunakan. Minyak jelantah pada akhirnya berujung menjadi limbah minyak, limbah minyak yang dibuang secara bebas mencapai sekitar 5000-15.000 liter. limbah minyak dapat menimbulkan masalah serius bagi 
lingkungan seperti menimbulkan racun bagi lingkungan dan mengganggu kehidupan biota (Kokasih, 2016).

Salah satu cara yang dapat digunakan untuk menyiasati persoalan limbah adalah dengan daur ulang, atau merubah dan memproduksi kembali limbah menjadi barang yang berdaya guna kembali. Daur ulang pada sampah dapat mengubah sampah yang tidak lagi dapat digunakanan berujung menjadi limbah yang berbahaya, menjadi barang dengan daya guna yang dapat digunakan kembali. Daur ulang dapat diterapkan pada berbagai jenis limbah, termasuk limbah minyak jelantah, limbah minyak jelantah yang tidak lagi dapat digunakan di rumah tangga dapat diolah kembali menjadi suatu hal yang dapat digunakan sehingga memperpanjang usia pakai minyak, salah satunya adalah dengan mengubah minyak jelantah menjadi sabun dan lilin. Daur ulang minyak jelantah menjadi sabun dan lilin dapat menjadi alternatif penyelesaian persoalan limbah minyak jelantah di tingkat rumah tangga yang dapat memberi manfaat bagi keluarga dengan menghasilkan barang berdaya guna dari sampah yang tidak lagi dapat digunakan.

Pengolahan limbah yang tepat perlu diterapkan oleh berbagai daerah di Indonesia sehingga dapat mengurangi produksi sampah rumah tangga yang amat besar, pengolahan limbah perlu dilakukan oleh tiap lini masyarakat baik skala desa, kota, dan negara. Penerapan pengolahan limbah dapat mulai dilakukan dari skala yang kecil yaitu dari rumah sendiri, dan selanjutnya dilakukan oleh lingkungan tempat tinggal salah satunya di desa-desa. Salah satu desa yang perlu melakukan pengolahan limbah adalah desa Donomulyo, Malang, yaitu sebuah desa yang terbilang besar dengan 4 dusun serta 71 RT di dalamnya, yang menjadikan desa ini memiliki penghuni serta rumah tangga yang amat banyak. Banyaknya jumlah rumah tangga menjadikan desa ini perlu memiliki alternatif pengolahan limbah yang mumpuni sehingga tidak mengakibatkan pencemaran bagi lingkungan sekitar.

Proses mendaur ulang sebuah limbah membutuhkan keterampilan dan keahlian yang mumpuni sehingga barang hasil daur ulang dapat tercipta, oleh karena itu dibutuhkan wadah untuk melatih anggota-anggota rumah tangga untuk mendaur ulang minyak jelantah menjadi sabun dan lilin. Salah satu wadah yang cukup efisien adalah dengan melakukan pelatihan. Berdasarkan penuturan di atas, maka diperlukan sebuah pelatihan daur ulang minyak jelantah menjadi sabun dan lilin di desa Donomulyo, Malang, Jawa timur..

\section{Metode}

Program pelatihan ini dilangsungkan dengan metode kerja sama antara mahasiswa peserta program MBKM di desa Donomulyo, kabupaten Malang dengan pihak pemerintah desa serta jajaran PKK desa. Program ini dilaksanakan dengan dua tahap, yaitu tahap diskusi bersama dengan aparatur desa mengenai program yang diimplementasikan pada masyarakat desa, selain itu juga dilakukan diskusi bersama dengan pihak PKK terkait pelaksanaan program pelatihan. Tahap kedua yaitu tahap penerapan program yang dilakukan melalui dua sesi berdasarkan masing-masing tema pelatihan yaitu sesi pertama pembuatan sabun dan sesi kedua pembuatan lilin.

\section{Hasil dan Pembahasan}

Program pelatihan pembuatan sabun dan lilin dengan pemanfaatan limbah berupa minyak jelantah memberikan beberapa luaran. Pelatihan yang ditujukan kepada anggota PKK (Pemberdayaan Kesejahteraan Keluarga) serta perwakilan dari 17 dusun yang ada di desa Donomulyo ini memberikan manfaat berupa ilmu mengenai proses pembuatan dan peserta 
pelatihan memperoleh praktik langsung dalam proses pembuatan. Pemberian pelatihan ditujukan agar nantinya penduduk setempat di desa Donomulyo dapat mengurangi limbah rumah tangga dengan cara memanfaatkannya melalui proses daur ulang. Hal ini dikarenakan dampak negatif yang ditimbulkan dari limbah rumah tangga sangat besar bagi lingkungan sekitar. Limbah rumah tangga dapat berdampak pada tingkat higienitas air yang menjadi sumber utama masyarakat untuk mandi dan mencuci (Hasibuan, 2016).

Air yang tercemar membuat masyarakat kesulitan dalam pemanfaatan air bersih dalam mendukung proses kehidupan manusia. Pencemaran air juga membutuhkan waktu yang cukup panjang dalam penanganannya. Selain itu, air yang juga dimanfaatkan untuk kepentingan industri juga dapat berdampak pada kondisi perekonomian masyarakat. Air yang menjadi komponen utama dalam penunjang kebutuhan sawah, membuat keperluan pertanian juga turut terganggu. Air yang mengandung pencemaran limbah, selain memunculkan bau busuk yang sangat mengganggu juga mampu menimbulkan berbagai penyakit kulit yang cukup membahayakan (Hasibuan, 2016). Oleh karena itu, penggunaan minyak jelantah yang merupakan limbah rumah tangga menjadi alternatif utama dalam pelatihan pembuatan barang habis pakai yang dapat dimanfaatkan oleh warga desa.

Tujuan pelaksanaan pelatihan tidak hanya untuk mencapai kondisi ramah lingkungan, namun juga diharapkan para peserta yang merupakan perwakilan dari komunitas dan warga desa Donomulyo dapat memiliki bekal inovatif dalam mengembangkan industri UMKM desa seperti yang sedang digencarkan oleh pemerintah. Menyadari akan peran penting UMKM dalam perekonomian Nasional, maka pemerintah berupaya untuk menstabilkan kondisi perekonomian melalui pendekatan pemberdayaan UMKM pada tiap-tiap wilayah desa di di Indonesia. (Rifai, 2013). UMKM mampu menjadi awal mula investasi bagi suatu desa. Di sisi lain, UMKM dapat bermanfaat dalam pengembangan kepiawaian berwirausaha masyarakat desa.

UMKM juga merupakan salah satu kelompok usaha yang mampu menghadapi permasalahan perubahan kondisi perekonomian dan memperoleh keuntungan dari kegiatan usaha tersebut (Tambunan, 2013). Hal ini juga disampaikan oleh Ketua komunitas PKK desa Donomulyo beserta ketua koperasi UMKM unit desa Donomulyo dalam menutup rangkaian kegiatan pelatihan pembuatan sabun dan lilin. Ada pun harapan tersebut yaitu melalui pelatihan ini diharapkan masyarakat desa mampu menjaga kondisi lingkungan dan mengembangkan kemampuan berwirausaha guna menjaga kestabilitasan perekonomian dan memperkenalkan hasil UMKM desa ke masyarakat di luar desa. Ketua koperasi UMKM unit desa Donomulyo, Kabupaten Malang menyampaikan bahwa ia siap untuk mewadahi hasil inovasi penduduk desa untuk dipasarkan dan diperkenalkan kepada masyarakat.

\section{Simpulan}

Limbah rumah tangga memiliki berbagai dampak negatif yang mampu mempengaruhi kehidupan masyarakat sekitar secara langsung. Pencemaran air dapat membuat masyarakat krisis air bersih yang menjadi sumber utama dalam mendukung proses kehidupan seperti mencuci, minum dan mandi. Kepentingan industri dan sektor pertanian juga turut memperoleh dampak negatif dari pencemaran lingkungan. Dampak negatif lainnya yang dapat dirasakan oleh masyarakat yaitu munculnya penyakit kulit yang cukup membahayakan. Melihat banyaknya dampak negatif dari limbah rumah tangga, maka pelatihan pemanfaatan limbah rumah tangga sangat bermanfaat dalam menjaga kondisi lingkungan. Selain mampu menjaga 
kondisi lingkungan, kondisi masyarakat yang mampu mengolah limbah rumah tangga menjadi benda pakai dapat meningkatkan potensi kestabilan perekonomian daerah sekitar melalui pemberdayaan UMKM sebagai wadah pengembangan minat dan bakat berwirausaha masyarakat sekitar juga sebagai upaya menguatkan perekonomian nasional.

\section{Daftar Rujukan}

Hasibuan, R. (2016). Analisis dampak limbah/sampah rumah tangga terhadap pencemaran lingkungan hidup. Jurnal Ilmiah Advokasi, 4(1), 42-52.

KLHK. (2020). Komposisi Sampah. Diakses dari https://sipsn.menlhk.go.id/sipsn.

Kokasih, D. (2016). Minyak Jelantah Berpotensi Cemari Air dan Tanah. Diakses dari https://www.greeners.co/berita/minyak-jelantah-berpotensi-cemari-air-dan-tanah.

Rifa'i, B. (2013). Efektivitas Pemberdayaan Usaha Mikro Kecil dan Menengah (UMKM) Krupuk Ikan dalam Program Pengembangan Labsite Pemberdayaan Masyarakat Desa Kedung Rejo Kecamatan Jabon Kabupaten Sidoarjo. Sumber, 100(100), 2-59.

Tambunan, T. (2013). Dampak dari Kebijakan “Satu Persen” Pajak pada UMKM. Jurnal Pengkajian Koperasi dan $U K M, 8,1-20$. 